\title{
News, Neighbours, and Commerce
}

\section{Newspaper Advertising in the Information Culture of the Dutch Republic}

\section{Andrew Pettegree and Arthur der Weduwen}

Andrew Pettegree is Professor of Modern History at the University of St Andrews and Director of the Universal Short Title Catalogue. He is the author of over a dozen books in the fields of Reformation history and the history of communication including Reformation and the Culture of Persuasion (Cambridge University Press, 2005), The Book in the Renaissance (Yale University Press, 2010), The Invention of News (Yale University Press, 2014) and Brand Luther: 1517, Print and the Making of the Reformation (Penguin, 2015). His recent projects include 'Preserving the World's Rarest Books', a collaboration with the international library community funded by the Andrew W. Mellon Foundation. His most recent book, The Bookshop of the World. Making and Trading Books in the Dutch Golden Age (co-authored with Arthur der Weduwen), will appear in March 2019.

Arthur der Weduwen is a researcher at the University of St Andrews and the author of Dutch and Flemish Newspapers of the Seventeenth Century (2 vols., Brill, 2017). An earlier version of this work won St Andrews University's Gray prize, and the Elzevier-De Witt prize in the Netherlands. His PhD (2018) is a study of government attempts to shape public opinion in the seventeenth-century Dutch Republic, entitled Selling the Republican Ideal. State Communication in the Dutch Golden Age. His most recent book, The Bookshop of the World. Making and Trading Books in the Dutch Golden Age (co-authored with Andrew Pettegree), will appear in 2019 with Yale University Press (in English) and Atlas Contact (in Dutch).

\begin{abstract}
The Dutch did not invent the newspaper - their genius lay, as in so many aspects of industry, in the refinement of the mechanisms of production and sale so as to maximise efficiency and profits. One of their imaginative contributions was the early adoption of paid advertising. The first advertisements appear in Dutch papers within years of their establishment, and by the middle of the century, many tradesmen and professional groups were beginning to recognise the benefit of using the newspaper to advertise their goods and services. Increasingly, too, the advertisements were mingled together with various sorts of public announcements, placed either by official bodies or private citizens: the notification of an upcoming market, appeal for help in the search for a missing child or fugitive servant, the offer of a reward for the return of lost or stolen goods. This article focuses on these public announcements; more specifically, it investigates the contribution made by newspaper advertising to the domestic information culture of the Dutch Republic.
\end{abstract}

Keywords: newspapers, Dutch Republic, advertising, public announcements, plague, crime, markets, almanacs

DOI 10.18352/emlc.64 - URL: http://www.emlc-journal.org

Publisher: Stichting EMLC, supported by Utrecht University Library Open Access Journals | The Netherlands Copyright: The Author(s). This work is licensed under a Creative Commons Attribution-NonCommercial 4.0 International License. 


\title{
News, Neighbours, and Commerce
}

\author{
Newspaper Advertising in the Information Culture of the Dutch \\ Republic
}

\section{Andrew Pettegree and Arthur der Weduwen}

The seventeenth century was the first age of the newspaper, and it is little surprise that a society as innovative as the Dutch Republic should have been an early adopter of this new addition to the media landscape. By 1618 Amsterdam had two competing weekly papers; and in contrast to many early newspapers which folded quickly, these two papers would be sustained for the best part of fifty years. The Dutch did not invent the newspaper - their genius lay, as in so many aspects of industry, in the refinement of the mechanisms of production and sale so as to maximise efficiency and profits. This is evident in their adoption of a single double-sided page which could be crammed with far more text than the German pamphlet proto-types. This was extremely cost efficient, if not necessarily well-designed for binding and preservation. Equally imaginative was their adoption of paid advertising. Here the Dutch were true innovators - the first advertisements appear in Dutch papers within years of their establishment, and by mid-century most issues carried two or three, always located at the end of the text on the reverse side. It would be another twenty years before advertisements became a common feature of papers in England, and later still in Germany and elsewhere. By the mid eighteenth-century newspaper advertising had become so important to the Dutch news culture that when Abraham Ferwerda was granted a license to publish a newspaper in Leeuwarden in 1752, it was only granted by the magistrates on the condition that he would never raise the price of advertising. ${ }^{1}$ Advertising, in effect, had become a public service.

Over the past years we have been engaged on a project to capture and analyse the texts of these advertisements. ${ }^{2}$ This project was stimulated in the first instance by the knowledge that they would offer a great deal of information on the contemporary book trade. In the first decades the advertisements were almost all placed by publishers offering their newly published titles. We wanted to compare these, where possible, to surviving copies: where they could not be found, these unmatched copies reveal lost books, titles that we know to have been published but cannot currently be matched to a copy in one of the world's libraries. ${ }^{3}$ Up to 1650 , a third of all books advertised in Dutch newspapers are such lost

1 Broersma, Beschaafde vooruitgang, 40-42.

2 Forthcoming as Der Weduwen and Pettegree, News, Business and the Birth of Modern Advertising.

3 For an initial survey of this investigation see, Der Weduwen and Pettegree, 'Publicity and its Uses'. 
books, revealing just over 400 new editions. Often these were the type of books that are not well represented in library collections today, because they were not meant for collecting, but for use. Catechisms, works of popular devotion, almanacs, self-help books and small format editions of the classics: these were the types of books that were intensively used by their owners, and often literally used to destruction. Reconstructing the history of these lost editions reveals vital aspects of the contemporary book market that will otherwise escape detection.

By the middle of the century, however, other tradesmen and professional groups were beginning to recognise the benefit of using the newspaper to advertise their goods and services, and it is this sort of advertising that has attracted most interest from historians, not least for the light advertisements can shed on patterns of consumption and changing cultural expectations in the sophisticated urban societies of northern Europe. ${ }^{4}$ Increasingly, too, the advertisements were mingled together with various sorts of public announcements, placed either by official bodies or private citizens: the notification of an upcoming market, appeal for help in the search for a missing child or fugitive servant, the offer of a reward for the return of lost or stolen goods. This article focuses on these public announcements; more specifically, it investigates the contribution made by newspaper advertising to the domestic information culture of the Dutch Republic.

\section{Stolen, Lost and Found}

The Dutch newspapers, in common with those published in other countries, were essentially a miscellany of foreign and diplomatic news. ${ }^{5}$ The four or eight pages of pamphlet editions, or the spare two sides of the Amsterdam papers, would be filled with a sequence of reports from the main continental news hubs. Only in the last quarter of the paper would readers find reports datelined from places inside the Dutch Republic, most usually from The Hague or Amsterdam: and much of this was likely to be occupied also by foreign news gleaned at the harbour, or a resigned and all too frequent note that, due to contrary winds, the English posts had not arrived. Of domestic news there was virtually nothing beyond reports of military campaigns, incoming Indiamen, or brief notices of the movements of the Prince of Orange and other eminent persons.

There were good reasons why this should be so. In common with other nations, the rulers of the Dutch Republic had no wish that their deliberative processes should be the subject of a running commentary. There was in fact plenty of political debate in the Republic, but mostly conducted in pamphlets. A political writer with a point to make could normally find a printer prepared to run off a few hundred copies of a pamphlet, especially

4 On early modern newspaper advertising see, amongst others, Van der Krogt, Advertenties voor kaarten, Kranen, Advertenties van kwakzalvers, Walker, 'Advertising in London Newspapers', Ferdinand, 'Constructing the Frameworks for Desire', Harris, 'Timely Notices', Harris, 'Printed Advertisements', Nevitt, 'Books in the News', Lyna and Van Damme, 'A strategy of seduction?', Hart, 'A British Atlantic World of Advertising?', and Botein, Censer and Ritvo, 'The Periodical Press'.

5 Der Weduwen, Dutch and Flemish Newspapers. 
as the printer could usually do so under the cloak of anonymity. The newspapers, since they relied on regular subscriptions, had to advertise their address prominently on every issue: they were therefore sitting targets if any of their reports displeased the magistrates. If publishers got into trouble it was invariably by overstepping the invisible line that determined the boundaries between what was acceptable in the reporting of domestic politics, and what was not. ${ }^{6}$ The only way to ensure that the next issue was not your last, was for publishers largely to avoid reporting domestic affairs.

So for newspaper subscribers, the most evocative glimpses of the lives of their fellow citizens would be found not in the news reports, with their marching armies and arriving ambassadors, sick cardinals and scheming Popes, but in the advertisements and public announcements. What do they tell us about the information culture of this vibrant and increasingly confident Dutch society? If we leave aside the advertisements for new books, which continue to be very numerous into the eighteenth century, the remaining advertisements and public announcements were concerned with a rich variety of commercial activities and the pursuit of trade. Private individuals took space in the papers to advertise goods and services, inventions, the sale of a business and mislaid financial instruments. The following are examples of mid-seventeenth century notices advertising new inventions, placed in Amsterdam and Haarlem newspapers. ${ }^{7}$

\footnotetext{
Salomon Coster, in The Hague, advertises a newly-invented standing clock, with privilege for twenty years. The clock is made according to the inventions of Christiaan Huygens, but this clock is much more precise than any other clock currently available. The clock is never subject to changes in weather or wind, and the clock can be customised by Coster according to any buyer's wishes. ${ }^{8}$
}

Mr Stevanus Keus, watch-maker in Amsterdam, advertises a newly-invented lantern with fantastic light, most appropriate to use in churches or grand halls, as well as for partridge and bird hunting. He also advertises a variety of handguns, available for a reasonable price. ${ }^{9}$

The inventor of the new hammer mills, who recently gained a twelve-year privilege to construct and sell these mills, warns his competitors that they will be fined 300 gulden if they are found to be reproducing said mills, and their equipment will be confiscated. A copy of the privilege can be read in Amsterdam in the Voetboogstraat, in the Diamant Boot. Any informer who notifies the inventor of a breach of privilege will enjoy a portion of the fine..$^{10}$

One did not have to be a potential purchaser to find many of these notices enticing. But numerous non-commercial announcements placed by individuals could also be a source of social fascination: a glimpse of lives of elegant ease, or, indeed, heart-breaking calamity. In 1657 the Weeckelijcke Courante van Europa carried an announcement of a remarkable theft:

Notification: on 13 April there was stolen in The Hague a large quantity of diamonds and jewellery, including a bracelet with 35 small diamonds and a little portrait of the Princess Royal. If anyone has

6 Examples in Der Weduwen, Dutch and Flemish Newspapers, 27-32, 37-40, 46-47, 59-60, 85-86, 602-603, $607-608,617-618,675,1053,1081,1135-1136,1385,1443$.

7 All extracts that follow are translations (lightly paraphrased) by the authors taken from the original copies. For a full survey see Der Weduwen and Pettegree, News, Business and the Birth of Modern Advertising.

8 Tijdinghen uyt verscheyde Quartieren (TVQ) 51 (Amsterdam: heirs of Broer Jansz, 22 December 1657).

9 Ordinaris Dingsdaegsche Courante (ODC) 2 (Amsterdam: widow of Joost Broersz, 14 January 1659).

10 ODC 5 (Amsterdam: widow of Joost Broersz, 29 January 1658). 
information about the theft then they are to address Pieter vander Veen in The Hague, Raphel Trappentier in Amsterdam, Abraham Verschuer in Rotterdam, Baudewyn de Man in Delft, or the Ouden Mareschalck in Leiden. The informant will remain anonymous, and receive a good reward. ${ }^{11}$

Rewards for the retrieval of lost jewellery and other price possessions could run up to 500 gulden, the equivalent to a year's salary for a successful independent trader or the pastor of one of the city churches.

Particularly prolific in the papers which appeared in The Hague in the 1650 s and 1660 s were notifications of lost financial bonds (obligaties), valued up to 12,000 gulden. Readers might well have wondered what lay behind this, or how it came to be such bonds, worth the equivalent purchase price of three houses on the fashionable side of Amsterdam, could have gone missing. But the papers were not all glitter and opulence: the advertisements parade their fair share of villains, dupes and family tragedies. The Dutch contributed generously to appeals for help to suffering fellow Protestants in other parts of Europe, so it was perhaps inevitable that this should stir the imagination of men like Hans Henrich Friese who solicited charitable donations for the town of Langenburg in Hessen, after a catastrophic fire. Friese pretended to have been sent by the magistrates of the town to raise financial assistance, and exhibited an impressive letter and seal as proof. All of this was completely untrue, as the readers of the Tijdinghen uyt verscheyde Quartieren were alerted, probably too late:

All good citizens are warned that a man named Hans Henrich Friese has gone round to raise charitable donations for the town of Langenburg in Hessen, stating that the town has burnt to the ground. He pretends to have been sent by the magistrates of the town to raise financial assistance, and produces an impressive letter and seal from the magistrates for this purpose. It has now been clarified that this is all untruthful and fraudulent. ${ }^{12}$

Since it was frequently necessary to jog the memory of newspaper readers that their subscriptions were due, those who went round collecting such sums claiming to be the publisher's representative were sometimes too casually believed, as Otto Barentsz Smient was forced to remind his fellow booksellers when he fell victim to a scam of this sort:

A young man of around 21 or 22 years of age, with a good physique, dressed in grey clothes and a cape, and well-spoken, has visited booksellers in various towns to demand payment for subscription to the newspaper of Otto Smient: he has claimed to be Adriaen Smient, saying that he is a nephew of Otto; all booksellers are therefore cautioned, not to give money to any person, unless the bill has been signed by Otto Smient; if any are able to point out the same person, they will enjoy a reward. ${ }^{13}$

The most heart-rending of all are the tales of lost or stolen children. The Dutch Republic was Europe's most urban society, and also one of the most mobile. Its rapidly growing cities were crowded with new citizens, often penniless refugees or migrant works, many passing through, others looking for a new life. In such circumstances, on the crowded streets and lanes, it was all too easy to be separated from a small child, or fall victim to an opportunistic crim inspired by hunger or desperation. 
A boy has been lost in Rotterdam, by name of Reynier or Reyn. He has yellowish, curly hair, and is dressed in green shorts and blue tights, underneath a white vest with yellow sleeves. ${ }^{14}$

Around fourteen days ago a woman was apprehended in Zierikzee, who had with her a small boy of around three years old, with a pale face and curled blond hair. The child is not hers, and is presumed to be stolen. Any information on the child is to be supplied to the burgomasters and aldermen of Zierikzee. ${ }^{15}$

On 25 April a boy of 10 years of age, named Hendrick Dircksz, ran away from home after a reprimand from his parents. Hendrick is pale of face, with brown hair, grey eyes, and dressed in bombazine. His father died of grief two weeks after his disappearance. Any information is to be supplied to the mother in Amsterdam, named Barbar Harmens, living on the Vinckestraat, where a good reward will be due. ${ }^{16}$

In a society of credit and debt, fortunes could be lost in an instant, and the newspaper advertisements contain many sad, cautionary tales of the fickleness of fortune, or the mysterious workings of God's providence. Who could read their weekly paper without feeling for the predicament of Abigael van den Hove, still hoping to locate her lost husband, eighteen years after he fled the family home?

Abigael van den Hove appeals for information of the whereabouts of her husband Doctor Dick van Dam, who fled The Hague in 1640 and is believed to hide out in the countryside. Van den Hove has not received any correspondence from her husband, but wishes to spend the remainder of her days with him in a proper Christian household. Dirck van Dam is around 70 years old, with blond hair, of moderate height, and has a scar on his nose. Van den Hove can be addressed at her house in The Hague in the Herdersstraat. ${ }^{17}$

Reading these sometimes heart-wrenching family stories and the salutary tales of easy fortunes lost to storms at sea or carelessness at home, is a reminder that the voyeuristic literature of Schadenfreude is in other respects poorly represented in the print culture of the Dutch Republic. We have relatively few execution pamphlets, or tales of notorious crime, from the Dutch Golden Age. The lavishly illustrated broadsheets that decorated the walls of many Dutch homes were mostly representations of sieges, battles, or maps and views of the new Dutch possessions abroad. There is no equivalent of the sort of broadsheets that filled the albums of the sixteenth-century Zürich minister Johann Jakob Wick, with their celestial apparitions, monstrous crimes, and miraculous rescues of starving families. ${ }^{18}$ Instead we have the newspapers, with their runaway servants, escaped criminals, mislaid children and the unidentified corpse of a young man who had fallen off a barge, presumably drunk, and drowned.

A servant named Anna has stolen from her employers a box with gold rings, silver spoons, bedding, clothing, kitchenware and more. The spoons are marked with the name Geurt Konings. She is 27 or 28 years old, speaks Clevish or Geldrian, is short, and has black hair. Any information leading to her whereabouts will be rewarded. ${ }^{19}$

14 Courante uyt Italien, Duytslandt, \&c. (CID) 51 (Amsterdam: Jan van Hilten, 19 December 1643).

$15 T V Q 47$ (Amsterdam: Broer Jansz, 19 November 1650).

16 TVQ 20 (Amsterdam: heirs of Broer Jansz, 16 May 1654) and Ordinarise Middel-weeckse Courante (oMWC) 20 (Amsterdam: widow of François Lieshout, 19 May 1654).

17 Haegsche Weeckelycke Mercurius (II) (HWM) 23 (The Hague: [Gerard Lodewijk van der Macht], 1658).

18 Mauelshagen, Wunderkammer auf papier; Pettegree, The Invention of News, 88-95.

19 TVQ 33 variant B (Amsterdam: Broer Jansz, 15 August 1643). 
On the $15^{\text {th }}$ of this month a coloured travelling bag with a sum of money fell off a cart between The Hague and Delft, and was picked up around the Hoorn bridge by an unknown person. They are kindly requested to present the bag with the money to the bookseller Johannes van Tongerloo in The Hague or to David Sufter, in Delft, living on the south corner of the Water Sloot; the finder will receive a reward of 100 gulden. ${ }^{20}$

On 30 November 1659 Jean del Beecq, a sly Walloon and a broker's apprentice in Leiden, stole from his employer many thousands of gulden. Del Beecq was born in Lille and is around 36 years of age. He is of moderate height, with short curled hair, like a Moor. His face is red, round, and full, and he has thick lips, broad shoulders and large legs. Whomever apprehends him will receive a 400 gulden reward, and a tenth of the stolen goods if they are retrieved, in accordance with the proclamation made in Leiden on 30 January $1660 .^{21}$

Thys Jacobsz, alias Thys Pellen, from Warmont, has been banned for twenty-two years to the Rasphuis in Leiden, but has cunningly escaped. He is a strong young carpenter, around 30 years of age, weighing around 200 pounds, and has little or no beard. Whoever is able to point out said Jacobsz to the bailiff of Warmont will receive a reward of 100 gulden, and will remain anonymous. ${ }^{22}$

A 30-year old man has drowned in the Zwarte Water near Zwolle, after embarking on the Amsterdam-Zwolle barge on 17 March. He was dressed in a dark brown cloth and black stockings, with a shirt signed with the letters I.W. Whoever knew this man can address themselves to the magistrates of Zwolle. $^{23}$

These were stories likely to resonate with precisely the social groups who made up the main body of newspaper readers, professional men and merchants, pastors and schoolmasters, the more successful artisan tradesmen. These were men who presided over extended households, and were happy to be reminded that apprentices could abscond, the servants were easily tempted by the possessions they dusted and cleaned as they went about their household chores, that the accumulation of wealth brought with it danger and the need for vigilance. These same householders were acutely aware that the good fortune they enjoyed rested on very fragile foundations. If they needed to be reminded of the need for eternal vigilance in the defence of God's bountiful gifts then the tales of misfortune and criminal activity they read in the papers were a constant aide memoire.

\section{Official Communications}

From the middle years of the century the dominant position of Amsterdam in the newspaper market was steadily eroded. New papers were established in The Hague, Haarlem, Rotterdam, Weesp, Utrecht and Leiden. If there was a national paper of record in the 1660 s and 1670 s it was the Oprechte Haerlemse Courante rather than any of the remaining Amsterdam papers, which were gradually conglomerated into a single title by order

20 HWM 5 (The Hague: [Gerard Lodewijk van der Macht], 17 January 1658).

21 CID 6 (Amsterdam: Otto Barentsz Smient, 7 February 1660).

22 CID 50 (Amsterdam: Otto Barentsz Smient, 15 December 1657).

23 CID 14 (Amsterdam: Otto Barentsz Smient, 2 April 1661). 
of the magistrates. ${ }^{24}$ This development had a profound impact on advertising markets. When publishers placed a notification for their new book titles in one or other of the main Amsterdam papers in the second quarter of the seventeenth century, they could be sure of reaching readers throughout the seven provinces. Thirty years later this was no longer true. Tradesmen, merchants and other advertisers adjusted their strategies accordingly. ${ }^{25}$

The proliferation of newspapers was partly a response to increasing demand; but it also reflected a positive desire on the part of the urban elites to have their own local newspapers. This provided the newspapermen, many of them well networked into the upper echelons of local society, with a degree of protection. When the States of Holland summoned Abraham Casteleyn to answer for a report that drew too boldly on confidential information, the Haarlem magistrates reminded their colleagues that only they could examine a Haarlem citizen: something they clearly did not intend to do. ${ }^{26}$

The city authorities could provide more tangible assistance with a generous bulk order for copies of the newspaper. They could also take space in the newspapers for official announcements, something which magistrates and other public bodies began to do frequently from the 1640 s onwards. The first announcement by a Dutch municipality was placed in 1634, but by the middle of the 1660 s almost sixty different magistracies had made use of the papers (see the appendix at the end of this paper for a full overview). ${ }^{27}$ This is where one might expect the clearest intersection between the newspapers and domestic information culture, given the frequency with which the urban authorities are required to publicise a new tax or regulation. In fact, the public announcements we see in the papers cover a relatively narrow range of commercial notifications: most prominently the alteration to the dates of markets, the renewal of a market after an intermission, a tart notification that the date of a market has been misprinted in an almanac. The following announcement, placed by the magistrates of Zwolle in one of the Amsterdam weeklies, is typical of dozens of municipal notifications found in seventeenth-century newspapers:

The magistrates and council of Zwolle give notice that the latest almanacs are not accurate in their descriptions of the timing of the Zwolle Kermis [festival], and therefore hereby notify that the Kermis will take place on Sint Jacob's Day if that day falls on a Sunday, and if it does not then it will take place on the first Sunday after Sint Jacob's Day. ${ }^{28}$

Municipal authorities and the West and East India Companies also used the newspapers to advertise a new barge or ferry service, a new school, the dates of markets, commercial auctions and new municipal building projects.

The burgomasters and regents of Gouda give notice that the St Jacob's market will from now on take place on the Monday after St Jacob's day, except when that day falls on a Monday, in which case the market will be held on the Tuesday. The cloth market will still be held on the day before the weighing day, according to tradition. ${ }^{29}$

24 Der Weduwen, Dutch and Flemish Newspapers, 27-47.

25 Der Weduwen, 'From piety to profit'.

26 Der Weduwen, Dutch and Flemish Newspapers, 675.

27 The first announcement was placed in the CID 21 (Amsterdam: Jan van Hilten, 27 May 1634).

28 CID 30 (Amsterdam: Jan van Hilten, 27 July 1641).

29 CID 28 (Amsterdam: Jan van Hilten, 13 July 1641). 
The magistrates of Amsterdam and Gouda give notice that work on a new canal-path between the cities will commence on 24 May 1657. The expansion of the canal between Gouda and the Goudsesluis will commence on 25 May 1657. Any person interested in working on the new canal-path is to present themselves at the city hall of Gouda, and those interested in working on the expansion of the Gouda canal are to appear at the house of Marten Roeten in Aerbrugge, near Alphen aan den Rijn. ${ }^{30}$

The regents of the chamber of Amsterdam of the West Indian Company give notice that those who wish to travel to New Netherland at the costs of the Company according to the previous announcements must present themselves at the office of the chamber before mid-December, and write themselves into the register, in order for the captains of the departing ships to regulate their preparations with greater ease..$^{31}$

The council of the Admiralty of Amsterdam gives notice that it will auction 328 cases of white and brown sugar, as well as tobacco, hides, syrup and timber on Tuesday 5 February at 9 am on the square before the Prinsenhof. The goods were captured by Captain Pieter van Brakel at the height of the river of Lisbon. The goods can be inspected at the warehouse on the Lijnbaan at the St Antonis gate on the Monday preceding the sale. ${ }^{32}$

The magistrates of Haarlem give notice that they have established a bank in their city, from which one can now purchase mortgages for all sorts of properties in their city. ${ }^{33}$

The burgomasters and regents of Weesp give notice that they have reinstated their Latin school, after it was closed for several years, for the education of the youth. The magistrates announce that they have appointed a competent and experienced rector, who will be able to teach students Latin and Greek, and that the burgomasters have gifted their rector with a suitable house in which he will be able to lodge students for a reasonable price..$^{34}$

The notifications of barge schedules and postal routes are also the sort of data that would be included in the ubiquitous almanacs.

The magistrates of Delft, Leiden, and The Hague give notice that for the benefit of travellers they have expanded the schedule of barges sailing between their cities. From 13 January onwards barges will depart each half hour from 10:30 am. ${ }^{35}$

All are notified that a new postal service for England has been established. From 7 pm on Friday evening onwards letters will be despatched weekly from the office in the Binnenhof opposite the Castelenye, where a post box will be located each Friday, and where all letters from England can be collected. ${ }^{36}$

And for the ubiquitous municipal lotteries of the seventeenth century, the newspapers played an essential role in promoting knowledge of the prizes, the date of the draw, and the place to which citizens should go to obtain their tickets. ${ }^{37}$

The magistrates of De Rijp give notice that registration for the lottery of the orphanage will close on 2 January 1659 , and the magistrates urge all to buy liberally out of Christian compassion. ${ }^{38}$

30 OMWC 19 (Amsterdam: widow of François Lieshout, 15 May 1657).

31 Oprechte Haerlemse Courant (ОHC) 23 (Haarlem: Abraham Casteleyn, 19 November 1658).

32 ODC 5 (Amsterdam: widow of Joost Broersz, 29 January 1658).

33 онс 6 (Haarlem: Abraham Casteleyn, 7 February 1660).

34 Courante uyt Italien ende Duytschlant, \& $r$. 25 (Weesp: Nicolaes Jacobsz, 23 June 1657).

35 онс 2 (Haarlem: Abraham Casteleyn, 14 January 1659).

36 Post-tydingen uyt's Gravenhage 78 [=76] (The Hague: Adriaen Vlacq, 16 September 1660).

37 Huisman and Koppenol, Daer compt de lotery.

38 CID 50 (Amsterdam: Otto Barentsz Smient, 14 December 1658). 
The magistrates of Veere in Zeeland give notice that because the municipal lottery was postponed due to unforeseen circumstances, the magistrates have now resolved and proclaimed that the lottery will take place in May, and that the final registration will take place on 18 April, at the house of Anthony van Deysen, notary in Veere, or with the appointed commissaries of the lottery. If there is not enough interest all payment will be returned, with $5 \%$ interest. Any inn-keeper who maintains a subscription list is instructed to burn a tar barrel on 15 April if they have raised 50 gulden in registration, in order to highlight the success of the lottery. ${ }^{39}$

The newspapers provided a vital service when unexpected events required a sudden adjustment to well-established commercial schedules. Outbreaks of infectious disease posed a particular challenge in this most commercial of societies, with travellers continuously on the road, bringing produce to the cities. A full quarantine was seldom possible, but the authorities did what they could.

The magistrates of Rotterdam give notice that because numerous people have died of the plague in various cities of Holland, and that more are afflicted by the same every day, that the magistrates will seek to prevent the spread of the plague in their city by forbidding all merchants or vendors of fur, wool, linen, hats or clothing, as well as waffle-vendors, from attending their annual market on 17 August..$^{40}$

Due to the contagious pestilence inflicted by God on many neighbouring cities and places, the magistrates of Groningen have ordered that no fruit or vegetables will be allowed to be imported into their city, including apples, pears, prunes, grapes, cucumbers, melons and pumpkins. Furthermore no cloth, wool, linen, hats, socks, hair, hemp, flax or cotton will be allowed to enter the city if it has been made or refined in an infected place. No clothes vendors, entertainers or waffle vendors will be allowed to frequent the upcoming annual market of 7 September. ${ }^{41}$

The magistrates of Kampen give notice that they have cancelled their annual Michael's market due to the present constitution of the times. No traders or vendors will be allowed into the city to offer their wares..$^{42}$

The magistrates of Enkhuizen give notice that because the Lord God has thus far spared them of the afflictions of the contagious disease, they have decided to prevent the spread of the plague into their city by cancelling their annual market, to have taken place on 8 October, and that no vendors will be allowed into the city to sell their wares. ${ }^{43}$

The plague epidemic of 1664 was particularly severe, and cities all over the Republic took action for their own protection. ${ }^{44}$ Neither Groningen, Enkhuizen nor Kampen had their own newspapers, so these announcements were all placed in the popular Haarlem paper. In this instance the Oprechte Haerlemse Courant functioned as a truly national medium of information.

The examples of public notifications found in seventeenth-century newspapers compose a far more limited range of official business than one would necessarily expect. Over the course of the century we estimate that the States General, the regional authorities and

39 онс 3 (Haarlem: Abraham Casteleyn, 19 January 1664).

40 TVQ 32 (Amsterdam: heirs of Broer Jansz, 9 August 1664).

41 онс 36 (Haarlem: Abraham Casteleyn, 6 September 1664).

42 онс 37 (Haarlem: Abraham Casteleyn, 13 September 1664).

43 онс 37 (Haarlem: Abraham Casteleyn, 13 September 1664).

44 Noordegraaf and Valk, De Gave Gods. 
municipalities between them issued at least 95,000 printed ordinances, regulating taxation, shipping, transportation, trade and poor relief, along with a myriad other details of civic life. ${ }^{45}$ These were seldom, if ever, referred to in the newspapers; indeed the newspapers carried the texts of far more foreign ordinances than those of domestic jurisdictions. This is a profound contrast with contemporary newspapers in other parts of Europe, and requires some explanation. The key point is that neither the authorities nor the publishers had much interest in utilising the newspapers in this way. Many ordinances were quite long and detailed, and space was always at a premium in the single half-sheet papers. The authorities, in any case, had their own efficient means to spread knowledge of a new ordinance. But the real point is that the audiences were not wholly congruent. Ordinances were aimed at a far wider segment of the Dutch population than were habitual newspaper readers; newspapers, on the other hand, hoped for a distribution over a far wider geographical area than might be directly addressed by a municipal ordinance. Therefore the announcements which municipal authorities did place, like those concerning markets and the plague, were announcements which appealed to this same spread out, national audience.

There was also the fact that newspapers worked to a fixed timetable, whereas official ordinances or proclamations could be issued at any time and on any day. The city employee charged with posting up official ordinances in Haarlem was required to present himself to the town hall twice a day at $11 \mathrm{am}$ and $4 \mathrm{pm}$, and might then be sent on his way, with attendant assistants to carry the bundles of paper and the municipal glue pot, to post them on the gates, official building and church doors of the city. ${ }^{46}$ This was a network of news that scarcely overlapped with Casteleyn's Oprechte Haerlemse Courante, which sold only a tiny portion of its print run within the city walls. ${ }^{47}$

Ordinances were intended to reach a broad range of the citizenry, and through such established procedures they could easily do so. But even those who moved in the privileged upper echelons of society, and would subscribe to a newspaper as a matter of course, would look elsewhere for really urgent news. This emerges very clearly from a recent book by Lodewijk Petram on the workings of the Amsterdam financial market, and the trading, sometimes feverish, in the shares of the East India Company. ${ }^{48}$ Most investors held their shares as a long-term investment, and the speculators devising ever more inventive forms of trading seems to have been a rather small segment of investors. But those dealing in shares required the latest information in a matter of hours, and newspapers, despite their lists of the cargoes of incoming East-Indiamen, played little part in shaping their strategies. Brokers got their intelligence by the most traditional of means, letters or conversation, and they attempted to shift the markets in exactly the same way, by planting rumours or pursuing inside information.

With this we are beginning to identify the very particular place that newspapers had taken up in the ecology of news. Much of the news they contained, the battles and sieges,

45 Pettegree and Der Weduwen, 'What was published?'. See also Der Weduwen, “'Everyone has hereby been warned"”.

46 Noord-Hollands Archief, Haarlem, Stadsbestuur van Haarlem 1573-1813 (3993), inv. 1252.

47 Der Weduwen, Dutch and Flemish Newspapers, 63.

48 Petram, De Bakermat van de Beurs. 
princely weddings and riots in faraway cities, had no likely immediate impact on the lives of their readers; conversely much of the news that citizens had to know, such as changes in tax rates, the decisions of the States of Holland or the municipality, did not appear in the newspapers at all. In 1671 the magistrates of Vlissingen issued a proclamation requiring all householders to furnish themselves with a firearm. ${ }^{49}$ This was not a negligible commitment, and it is not easy to imagine how citizens could speedily have done what was required of them. Such an instruction would also have given them a far more immediate sense of the darkening international political climate than the procession of reports in the newspapers.

\section{The Essence of the Newspaper}

What, then, were these newspapers? Part recreation, part contemporary history, part an essential manual of instruction for those who would be well equipped for the conversation of polite society; but certainly insufficient in themselves as a news service for those involved at almost any level in public affairs, whether members of the Amsterdam city council, or a long suffering Vlissingen farmer searching for a firearm. What newspapers can do, not least through their advertisements, is offer us a window on social change. That much is especially clear from the investigation of one annual run of the Gazette d'Amsterdam from the 1690 s, one of a number of French-language newspapers that served not only a local audience, but as an alternative for French readers to the stifling sycophancy of the Paris Gazette..$^{\circ}$ The advertisements could not be more different in tone from those of the sober publications of the Amsterdam newspapers of the 1640s, which advertised devotional texts, Bibles, catechisms and self-help manuals. The Gazette d'Amsterdam obviously has a very different clientele, as most of the books listed are racy exposés of the loose morals of the court of Louis XIV, thinly disguised as fiction. Besides these book notices, the most frequently advertised services are those of Parisian doctors offering miracle cures, makers of sweets and other trifles. If the anticipated reader of the Dutch newspapers of the 1640 s was a sober and devout citizen household, the readers of the Gazette d'Amsterdam seem to have been mostly lascivious hypochondriacs.

It may seem perverse to conclude with the reflection that newspapers played a subsidiary role in purveying real news in the seventeenth-century Dutch Republic. But one rather should see this as an indication that the existing mechanisms and conduits for news functioned very efficiently, in cities like Groningen with no newspaper, as well as the great newspapers hubs in Holland. Newspapers were not irrelevant to news culture - by providing a miscellany of news from around the continent they helped build a wider circle of informed citizens than in any part of Europe. But with the advertisements and announcements, newspapers began to embrace a wider cultural role, and begin the transition to the all-round purveyors of stimulation and entertainment that newspapers would progressively become from the eighteenth century onwards.

49 Warschouwinge, bailliu, burgemeesters, schepenen, ende raden der stadt Vlissingen, hebben geordonneert, dat yder persoon hem sal hebben te voosien van behoorlijck geweer (Vlissingen: Abraham van Laren, 1671). 50 Rétat, La "Gazette d'Amsterdam"; Bots, 'La Gazette d'Amsterdam'. 


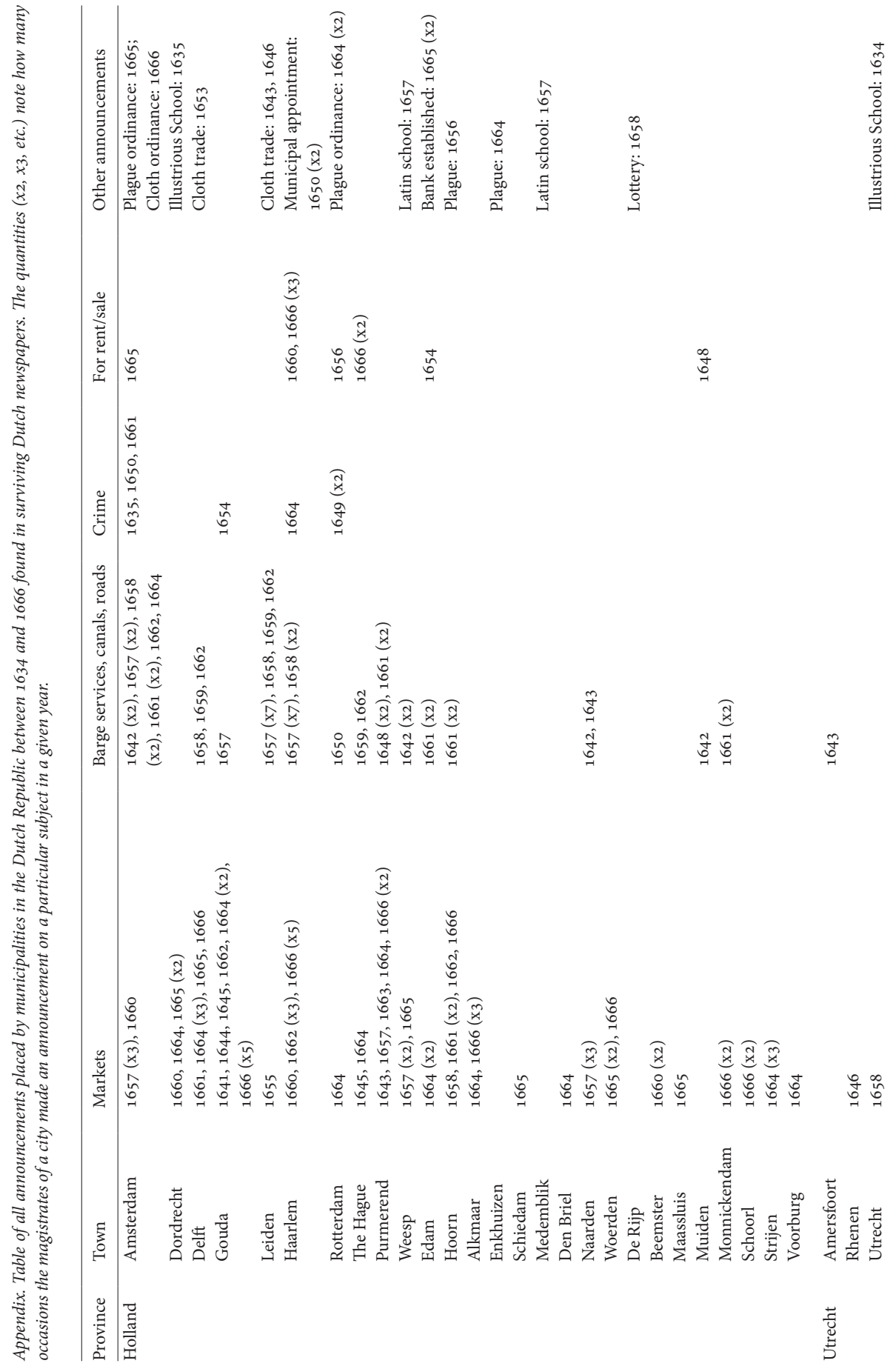




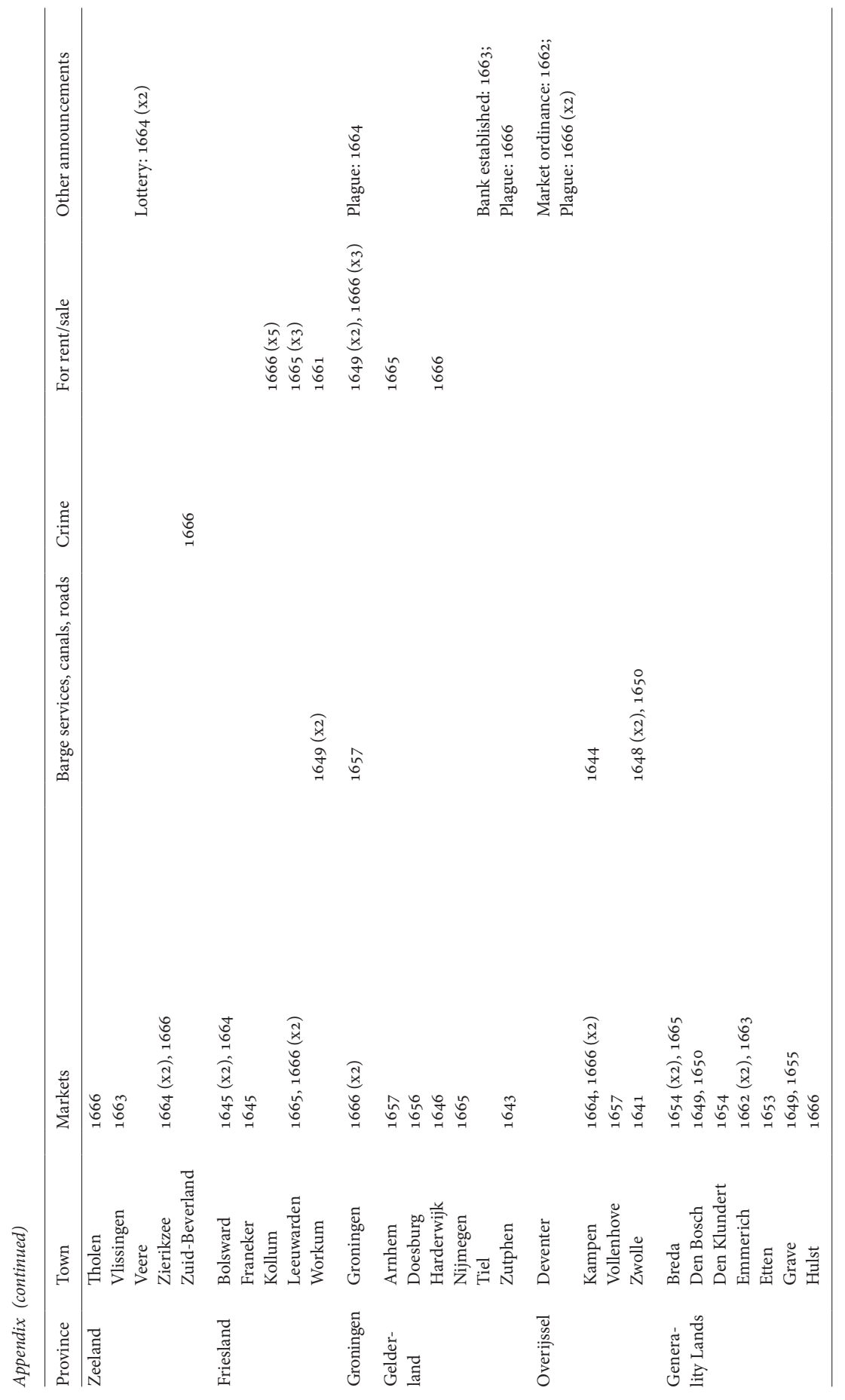




\section{Bibliography}

Botein, Stephen, Jack R., Censer and Harriet Ritvo, 'The Periodical Press in Eighteenth-Century English and French Society: A Cross-Cultural Approach', Comparative Studies in Society and History 23 (1981/3), 464-490.

Bots, Hans, 'La Gazette d'Amsterdam entre 1688 et 1699: Titres, éditeurs, privilèges et interdictions', in Henri Duranton, Claude Labrosse and Pierre Rétat (eds.), Les Gazettes Européennes de langue française (XVIIe-XVIIIe siècles) (Saint-Étienne 1992).

Broersma, Marcel, Beschaafde vooruitgang: De wereld van de Leeuwarder Courant, 1752-2002 (Leeuwarden 2002).

Ferdinand, Christine, 'Constructing the Frameworks for Desire: How Newspapers Sold Books in the Seventeenth and Eighteenth Centuries', in Joad Raymond (ed.), News, Newspapers and Society in Early Modern Britain (London 2002), 157-175.

Harris, Michael, 'Timely Notices: The Uses of Advertising and its Relationship to News during the Late Seventeenth Century', in Joad Raymond (ed.), News, Newspapers and Society in Early Modern Britain (London 2002), 141-156.

Harris, Michael, 'Printed Advertisements: Some Variations in their Use around 1700', in Robin Myers, Michael Harris and Giles Mandelbrote (eds.), Books For Sale: The Advertising and Promotion of Print since the Fifteenth Century (New Castle, DE 2009), 57-86.

Hart, Emma, 'A British Atlantic World of Advertising?: Colonial American "For Sale" Notices in Comparative Context', American Periodicals: A Journal of History, Criticism and Bibliography 24 (2014/2), 110-127.

Huisman, Anneke and Johan Koppenol, Daer compt de lotery met trommels en trompetten! Loterijen in de Nederlanden tot 1726 (Hilversum 1991).

Krogt, P.C.J. van der, Advertenties voor kaarten, atlassen, globes e.d. in Amsterdamse kranten, 1621-1811 (Utrecht 1985).

Kranen, D., Advertenties van kwakzalvers \& meesters in de oprechte Haerlemse Courant, (1656-1733) (Ede 2007).

Lyna, D. and I. van Damme, 'A strategy of seduction? The role of commercial advertisements in the eighteenth-century retailing business of Antwerp', Business History 51 (2009/1), 100-121.

Mauelshagen, Franz, Wunderkammer auf papier: die "Wickiana" zwischen Reformation und Volksglaube (Epfendorf 2011).

Nevitt, Marcus, 'Books in the News in Cromwellian England', Media History 23, (2017/2), 218-240.

Petram, Lodewijk, De Bakermat van de Beurs. Hoe in zeventiende-eeuws Amsterdam de moderne aandelenhandel ontstond (Amsterdam 2011).

Pettegree, Andrew, The Invention of News: How the World Came to Know About Itself (London 2014).

Pettegree, Andrew and Arthur der Weduwen, 'What was published in the seventeenth-century Dutch Republic?', Livre. Revue Historique (2018/1), 1-22.

Rétat, Pierre, La "Gazette d'Amsterdam", miroir de l'Europe au xviıe siècle (Oxford 2001).

Walker, R.B., 'Advertising in London Newspapers, 1650-1750', Business History 15 (1973/2), 112-130.

Weduwen, Arthur der, Dutch and Flemish Newspapers of the Seventeenth Century, 1618-170o 2 vols. (Leiden 2017).

Weduwen, Arthur der, “'Everyone has hereby been warned." The Structure and Typography of Broadsheet Ordinances and the Communication of Governance in the Early Seventeenth-Century Dutch Republic', in Andrew Pettegree (ed.), Broadsheets: Single-Sheet Publishing in the First Age of Print (Leiden 2017), 240-269.

Weduwen, Arthur der, 'From piety to profit: the development of newspaper advertising in the Dutch Golden Age', in Siv Gøril Brandtzaeg, Paul Goring and Christine Watson (eds.), Travelling Chronicles: Episodes in the History of News and Newspapers from the Early Modern Period to the Eighteenth Century (Leiden 2018), 233-253. 
Weduwen, Arthur der, and Andrew Pettegree, 'Publicity and its Uses. Lost Books as Revealed in Newspaper Advertisements in the Seventeenth-Century Dutch Republic', in Flavia Bruni and Andrew Pettegree (eds.), Lost Books. Reconstructing the Print World of Pre-Industrial Europe (Leiden 2016).

Weduwen, Arthur der, and Andrew Pettegree, News, Business and the Birth of Modern Advertising. Advertisements and Public Announcements in Dutch and Flemish Newspapers, 1620-1675 (Leiden forthcoming). 